\title{
Connecting Smallholding Farmers: Analysis of Agricultural Market Information Systems (The Case of Wondogenet Wereda, SNNPR, Ethiopia)
}

\author{
Mitiku Kebede $^{1, a, *}$, Shiferaw Mitiku Tebeka ${ }^{2, b}$ \\ ${ }^{1}$ School of Commerce, Addis Ababa University, P.O.BOX: 3131, Addis Ababa, Ethiopia \\ ${ }^{2}$ College of Business and Economics, School of Commerce, Addis Ababa University, P.O.BOX: 3131, Addis Ababa, Ethiopia
}

*Corresponding author

A R T I C L E IN F O A B S T R A C T

Research Article

The study aimed to identify the major challenges that affect the market information system, assess the possible mechanism that would increase their speculative and bargaining capacity power and to explore feasible information system solutions. Data were collected with structured questionnaire from104 farmers of different market using clustered sampling techniques. Descriptive research

Received : $14 / 09 / 2020$

Accepted : 16/03/2021 design and mixed (qualitative and quantitative) research approach vis-à-vis value chain approach is applied and developed an intermediary driven value chain model that links farmers to the market as a way to improve the unidirectional, selectively beneficiary traditional system. Using nine criteria on the multitude of alternative information delivery mechanisms for small holding farmers, Interactive Voice Response based system is found to be of highly effective. Restructuring the market information by bringing the most important wholesalers in to the system, enhancing the functionalities of the market by creating localized price data and creating demand forecasting platform by distinguishing crops that continuously face marketing problems are suggested as shortterm action while, increasing economies of scale in production and distribution by consolidating farmers' cooperatives, encouraging the development of third-party logistics, investing on the physical agro-logistics infrastructure to support long-distance, high-volume agricultural product transportation modes as well as increasing the refrigerated storage capacity at wholesale markets to nurture cold chain technologies are very crucial tasks in the long run.

Agriculture

Ethiopia

Information System

Market Linkage

Value Chain

\section{Introduction}

Ethiopia is the second-most populous country in SubSaharan Africa with a population of 102 million and population growth rate of $2.5 \%$ (World Bank, 2017). The per capita income is estimated to be $\$ 861$ (IMF World Outlook, 2017). Agriculture is the mainstay of the Ethiopian economy and underpins its development process. Even though, the average smallholding farmers' farm size is 1.2 hectares, they are responsible for $85 \%$ of agricultural production (Access Capital, 2012). As in the case of the rest of developing world, their role in domestic, regional, and international markets is very limited. The sector is characterized by rain fed and subsistence farming, low quality and insufficient market information, very little know how and low bargaining power, unstable price, lack of trust among trading partners, uncoordinated markets and as well as poor forward and backward market linkage. According to Asian Development Bank (2016), the five key areas that constrain the efficient operation of agricultural logistics are scale of operation, packaging standards, product grading and food safety, market information systems, and cold chain technology. UNDP (2012) also stated that farmers with accurate, reliable, timely, and appropriately presented information are able to boost their living standard, wealth and health of their family. Moreover, such access to information should be buttressed by well-functioning agro-logistics infrastructure mainly; transportation facilities, smooth information and communication system and timely input provision.

Farmers living in rural area where transportation, storage, and communication infrastructure facilities are not available, the only market place will be the local market found in the neighbourhood where the main sources of price information are local buyers and brokers. However, these economic agents do not give them the right bargaining power to sale their product with the precise market information. Buyers on the other hand are government-licensed exporters, wholesalers, and intermediaries (middlemen) who have a warehouse to store and transportation facilities to take and sale that make them the main beneficiaries from the system. Besides, for any product to reach the hands of customers, it passes through a 
long supply chain, which consists of multiple brokers who take a profit margin at every stage. Since qualities are checked visually, goods are opened and repackaged every time, which seriously endangers the quality and quantity of the good and creates huge price overhead on the final market price.

These sequential and routine factors in return lead to so many problems. First, it discourages the farmers from producing beyond their subsistence level. Second, even though they produce a surplus, the lion share goes to other stakeholders in the market: mainly the merchants and the brokers. This is because they are forced to sell at lower price by the mediators of the market. Third, the farmers will be incapacitated to purchase inputs for upcoming years, which further lead them to either forced borrowing or low-quality production. The perishable nature of their product and the year-round production, further limits their bargaining power. From the current economic policy, Agricultural Development Led Industrialization (ADLI), it is easy to depict that empowering smallholding farmers and their economic activity have been the focus. However, a little is done to its realization.

Having these problems at hand, there are only sporadic and incomplete researches done in the area peculiarly to improve smallholding farmers' market linkage. So, in this research, these core problems are addressed as it proposes mitigation mechanisms at different levels. Mechanisms to improve their back and forth linkage and to ensure their access to updated, accurate, and reliable information for better bargaining power are discussed in detail.

The study intended to investigate the agro-logistics gap hindering the effectiveness of small holding farmers producing perishable agricultural products and evolve a value chain model as an intermediary driven approach. More specifically, the study aims to:

- Examine the quality of agricultural market information systems

- Assess the effectiveness of agricultural market information systems adopted by small holding farmers in Ethiopia (Wondogenete Wereda)

- Evolve alternative value chain model to small holding farmers producing perishable agricultural products as an intermediary driven approach

- Identify the major challenges that affect agricultural market information system's effectiveness on small holding farmers speculative and bargaining capacity power

The study aims to answer the following research questions:

- How quality is the agricultural market information systems (Wondogenete Wereda)?

- What is the effectiveness of agricultural market information systems adopted by small holding farmers in Ethiopia (Wondogenete Wereda)?

- What kind of alternative value chain model will be ideal to small holding farmers producing perishable agricultural products as an intermediary driven approach?

- What are the major challenges that affect agricultural market information system effectiveness on small holding farmer's speculative and bargaining capacity power?

\section{Agricultural Market Intelligence}

E-agriculture, or ICTs in agriculture, is about the conceptualization, design, development, evaluation and application of innovative ways to use information and communication technologies (ICT) in the rural domain, with a primary focus on agriculture (FAO, 2016).

E-agriculture transforms the way actors in agricultural value chains practices from the following perspectives. Eagriculture transforms transform the way how actors collect, analyze, store and share agricultural information; creates efficiencies in rural markets by lowering transaction costs, information asymmetries and improved market coordination; reduces wastage in various stages from the field-to-fork value chain; nurtures the development of trust-based relationships between value chain actors; reduce uncertainty and enhance preparedness and response to climate change, disasters, and other agricultural risks (FAO, 2016).

Recently, the concept of Information Communication Technology for Development (ICT4D) is getting much acceptance in different parts of the world, especially, in developing countries. A good example of the impact of ICT is that of farmers getting better market price information and thus boosting their income in Ghana using their association ESOKO and in Ethiopia through Ethiopian Commodity Exchange Market. In Kenya, India, Bangladesh, and Burkina Faso, regional market information centers, and Short Message Service (SMS) deliver timely and accurate pricing information to producers and traders. In Ethiopia, an internet auction for specialty coffee resulted in significantly higher prices for coffee farmers. ICT is also considered as the basic tools to produce 60 percent more food by 2050 (FAO, 2017)

On the other hand, smallholding farmers are the main actors in the global agriculture arena. First, although smallholders constitute the majority of the poor, they are a major contributor to national and global food security (FAO, 2015). There are approximately 1.5 billion smallholder farmers in (In Africa, on average, 80 per cent of landholdings are smaller than 2 hectares. 1 hectare $=2.47$ acres $=10,000$ square meters.) the world, (Ferris et al., 2014) and about 2.5 billion people directly or indirectly depend on them for their livelihoods (IFAD and UNEP, 2013). Second, smallholders are key partakers in economic growth in their contribution to farm productivity and export sector (Sen, 1962; FAO, 2013). In fact, according to World Bank (2008), income growth generated by agriculture is up to four times more effective in reducing poverty than growth in other sectors.

Third, they play a major role in ensuring social and environmental sustainability of the agricultural sector (Tadele and Gella, 2012). However, 80-90\% of their productions are sold informally, through transactions at the farm gate, roadside sales, village and rural assembly markets, and urban wholesale and retail markets (UNICTAD, 2015) and they are locked in poverty with increasingly small parcels of land due to the continuous crowding out threat from middle and large-scale farmers.

\section{Market Linkage}

According to Shepered (2007), farmers could create linkage in various formats the main ones including:(a) farmer to domestic trader; (b) farmer to retailer;(c) linkages through a leading farmer; (d) linkages through 
cooperatives; (e) farmer to agro-processor; (f)farmer to exporter; $(\mathrm{g})$ and contract farming. It is generally agreed that, transformation from subsistence to more marketoriented agricultural systems is a necessary condition for smallholders to move out of poverty and achieve food security (Von Braun, 1995). Deeper supply integration of smallholders is considered an important means of achieving these objectives. In the past two decades, the expansion of supply chains and the rapid development of ICTs in developing countries have provided new opportunities for the development of smallholder farming businesses.

Information is currently regarded as one of the factors of production like other factors such as labor, capital and land (Dralega, 2007; Rao, 2007). The experiences of most countries indicate that rapid development of ICT, which facilitates the flow of data and information, has tremendously enhanced the knowledge management practice in agriculture (UNDP, 2012). It will help the business firms, farmers, researchers, government ministries and consumers who are working in the sector directly or indirectly. Moreover all the Pre-cultivations: including crop selection, land selection, calendar definition, access to credit, etc.; crop cultivations and harvesting: including land preparation and sowing, input management, water management and fertilization, pest management, etc.; and Post-harvest: including marketing, transportation, packaging, food processing, etc. are included in the process (World Bank et al., 2012).

There are two types of market information: formal and informal. Formal information is typically written and may be divided into data (numbers and other raw information) and processed information that is based on interpretation and analysis of the raw data. Informal information consists of information obtained through conversation and business transactions. It is mainly sourced from friends and relatives. Gossip is one of the most important sources of informal information. Sources of formal information include public agencies, Cooperatives, commodity groups, and a wide array of private providers including commercial vendors, government supported or private owned agricultural and non-agricultural media and, in some cases, in-house analysis in which large farms hire professionals to interpret information.

\section{Value Chain Approach}

The term value chain first popularized in a book published in 1985 by Michael Porter who used it to illustrate how companies could achieve what he called "competitive advantage" by adding value within their organization. Subsequently, the term was adopted for agricultural development purposes. Currently it is termed as an extended supply chain or marketing channel, which embraces all activities needed to produce the product, including information/extension, planning, input supply, and finance.

A major subset of value chain development work is concerned with ways of linking producers to companies, and hence into the value chains. Such arrangements frequently involve contract farming in which the farmer undertakes to supply agreed quantities of a crop or livestock product, based on the quality standards and delivery requirements of the purchaser, often at a price that is established in advance. Companies often also agree to support the farmer through input supply, land preparation, extension advice and transporting produce to their premises (Shepered, 2014).

There are three types of value chain integrator models, which are mostly used to analyze the value chain in the market namely; producer-driven models, buyer-driven models and intermediary-driven models (Negasa, 2015).

Producer-driven models - These chain integrators include initiatives such as cooperatives and farmer-owned businesses. The models have had a mixed record of providing members with economic benefits in terms of access to dynamic markets but rarely focus on providing an effective marketing channel (Vorley et al., 2008)

Buyer-driven models -This stand for a more forward relationship between the buyer and the producer, which is frequently managed and maintained by a retailer or a processor in the industry. There are various cases in which buyers had to include smallholders in their business model, as smallholder farmers were the only sources of raw materials available.

Intermediary-driven models -these models create an alternative to producer and buyer-driven models through integrating forward for producers or backwards for retailers or processors is time demanding and expensive (Vorley et al., 2008). In essence, these are attempts to cut out the middlemen to save costs, but in reality, they often deemed result in high transaction costs and mixed outcomes. For that reason, working with middlemen might not be such a bad alternative as it is often perceived.

The impact of ICTs in promoting agricultural value chain efficiency has become very indispensable. Especially due to the mass usage of mobile phone and the affordability of the technology, its impact is tremendously increasing. Farmers in Burkina Faso use ICT to share new production, processing and marketing skills. In Mali linking Malian smallholders and exporters use it to connect with global consumers; In Kenya, for index-based agriculture insurance on agricultural inputs; applications such as MPesa are supporting access to mobile payment services for a large percentage of those without banks, thereby facilitating transactions in the value chain. In Liberia and South Africa, ICTs are being used to improve forest governance and to alleviate food security related problems respectively.

ICTs are also being used to strengthen the capacity of extension officers to reach farmers with timely and accurate information and, at the same time, help capture data from the field. These farmer representatives are trained to use ICT applications on a smart-phone to provide agricultural information and extension support. Most market price information is now delivered to farmers via SMS (Grameen Foundation, 2014).

\section{Value Chain Models for Connecting Smallholder Farmers in Ethiopia}

Value chain approach to farmers' development involves addressing the major constraints and opportunities faced by them at multiple levels of a given value chain. This can include a wide range of activities such as facilitating access to cheaper or better inputs, strengthening the delivery of farmers' production, and their access to higher-value markets. 
In the traditional selling farmers are isolated from the end-consumer and have little control over the input and their productions; products are just pushed into the market. Most products involve a number of non-value adding supply chain actors before they reach the final consumer. Input suppliers, producers, processors, wholesalers and retailers produce, transform, store, and transfer or market the product, either reducing or adding to its value at each step in the process. However, in a value chain marketing system, farmers are linked to consumers' needs, working closely with suppliers and processors. It is based on integrated transactions and information. Consumers purchase products that are produced according to their preferences. The farmer becomes the core link in producing the products that the consumers desire. Similarly, through flows of information and products, consumers are linked to the needs of farmers. Under this approach, through continuous innovation, the returns to farmers can be increased and livelihoods enhanced.

Developing value chains is often about improving access to markets and ensuring a more efficient product and information flow while ensuring that all actors in that chain benefit. Therefore, changing agricultural contexts to the benefit of the mass, cutting the protracted delivery channels and inculcating pro-poor development strategies all call for value chain strategies to be implemented.

In the traditional market flow, there is no backward flow of information or a feedback from the end users or any agent for that matter. Besides the fact that the flow of information is not back and forth, the system itself is not capable to handle the complex production-delivery processes. Taking a grain market as an illustration, Ethiopian Commodity Exchange has developed a model for the traditional market structure (refer Figure 1)

As it can be seen there is no any direct contact between the producer and end consumer. The grain market structure taken from Ethiopian Commodity Exchange, after the application of value chain method, with a well-organized market structure format, revealed the same channel with an intermediary driven pattern. In this model, farmers are well informed about the market structure, the market price, and the delivery mechanisms. As a result, their bargaining power is boosted, their income has increased, and they are producing beyond subsistence level (refer Figure 2).

\section{Materials and Methods}

\section{Description of the Study Area}

Wondo Genet is a resort town in Ethiopia located southeast of Shashemene in Sidama zone of the SNNPR with a latitude and longitude of $7^{\circ} 1^{\prime} \mathrm{N} 38^{\circ} 35^{\prime} \mathrm{E}$ and an elevation of 1723 meters. It is one of the 19 weredas in Sidama zone embracing 14 kebeles (13 rural and 1 urban) in it. Oromia Region surrounds it in the eastern and northern part and by Tula sub-city and Malga wereda in southern and south-eastern side. The statistics shows that the total population of the Wereda is around 148,202 and the population density is 9.6 per kilometer square. The area totally is $151.45 \mathrm{KM}^{2}$ or 15145 hectares. According to the SNNPR Livelihood Report (2017), Wondogenet is the part of the Awassa "Chat" and Enset Livelihood Zone where household cash incomes are high and food production is relatively low. It is a food secure area of SNNPR that attracts migrant labor from other parts of the region. This is a densely populated, midland (woinadega) livelihood zone which consists of $61.56 \%$ of the area and the rest $(38.44 \%)$ as "Dega", located in the eastern half of Awassa Wereda of Sidama Administrative Zone.

The area is one of the naturally gifted areas in Ethiopia. Mixed farming is the main agricultural system in this livelihood zone. "Chat", sugarcane, avocado, mango and vegetable including potato, tomatoes and others are the main cash crops. Enset, maize, haricot beans, and Irish potatoes are the main food crops. Middle and better off households generally cultivate their land using plow oxen, whereas the poor cultivate mainly by hand. Irrigation is the most common practice in the area mainly to produce their cash crops. The types of livestock reared are cattle, goats, and donkeys. Donkeys are important for transportation, particularly to bring their produce to the local market. In addition to this, most middle and better off families have horse carts for transportation. Most grazing lands are communal and there is almost no migration of livestock out of the zone. Opportunities for casual agricultural work are relatively plentiful in this livelihood zone, both for local poor households and for migrant laborers from nearby areas.

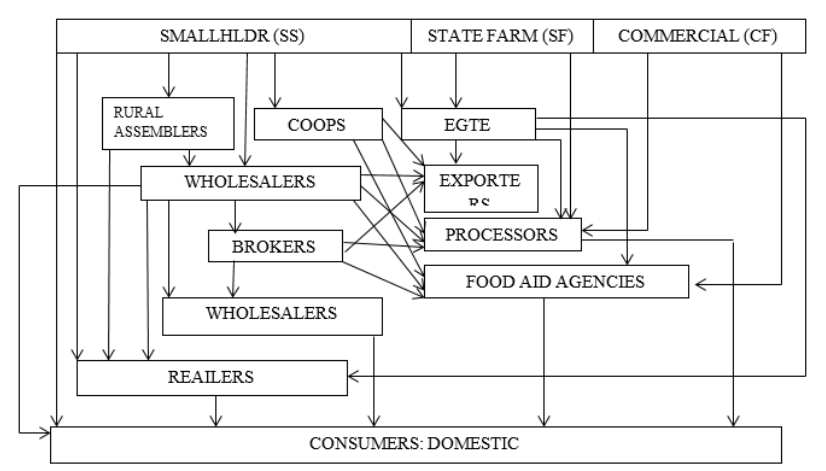

Figure 1. Market structure for grain products in Ethiopia

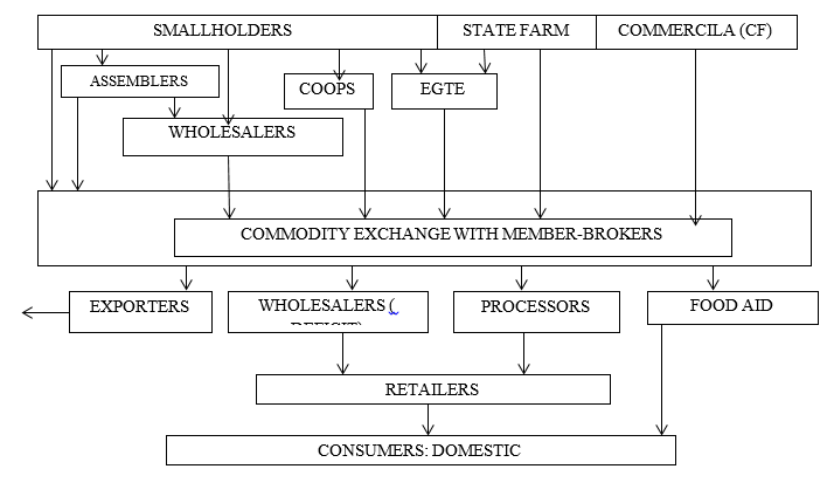

Figure 2. Grain Market Structure with in Ethiopia Commodity Exchange

Source: Ethiopian Commodity Exchange, 2017

\section{Population, and Methods of Data Collection and Analysis}

To undertake this study, both primary and secondary data were used. The primary data was collected from small holding farmers using structured questionnaires that include both open and close ended questions. Key informant interview was taken from Wondogenet Wereda Production Exchange and Unions Bureau. Since the 
majority of the farmers are illiterate. From the total 104 questionnaire distributed to small holding farmers only 94 of them were collected with the direct assistance of data collectors. The questionnaire was translated in to the local Sidamigna language because the majority people speak this language. Secondary data is also sourced from Wondogenet Wereda Exchange and Unions Bureau's annual reports.

Clustered sampling technique was used to draw the samples from the different market centers where various commodities are traded. There are five market centers namely," Chuko" and "Beleche" where "Chat" is the main trading commodity;" "Kella" where the main market center for various food and cash crops and as well animals hides and skins; "Aruma" and "Wosha" where basically food crops are brought for trade. The Productions come from all the fourteen kebeles and neighboring regions of the Wereda to these markets. The producers of various cash and food crops such as "Chat", sugarcane, avocado, potato, tomato and grain are included in the study.

Then, the sample size for the study was determined by using the formula for a cross sectional household-based survey developed by Cochran (1977).

$$
n=\frac{\frac{Z^{2} p(1-p)}{d^{2}}}{1+\frac{1}{N}\left(\frac{Z^{2} p(1-p)}{d^{2}}-1\right)}
$$

Where $\mathrm{Z}$ is the upper $\mathrm{a} / 2$ points of standard normal distribution with $\alpha=0.05$ significance level, which is $\mathrm{Z}$ $=1.96, \mathrm{~d}$ is the degree of precisions (0.04), $\mathrm{p}$ is taken as 0.5 . The estimated sample size is 104 households of which 94 of the questionnaires were found viable for the analysis.

Value chain approach is given an emphasis to explain the details of market linkage and information system among the economic agents. This approach emphasizes on the backward and forward relation among the economic agents. Of the three chain integrators, Intermediary driven model is going to be discussed because of its practical nature in the area. Based on the chain created each actor in the market could add an important value to the information.

The collected data analyzed using both quantitative and qualitative techniques. The segments that have a direct relation with the research question were analyzed properly. The data was encoded in SPSS and different descriptive statistics, cross tabs, frequencies, and the like were used for the analysis purpose. Finally, the output from SPSS was displayed using simple descriptive statistics like percentages, frequency, mean, standard deviation, maxim, minimum and results were presented using tables, charts, line and bar graphs. Moreover, to show the income disparity among farmers an econometric model is used for the display purpose.

\section{Results and Discussion}

\section{Demographic and Socio-Economic Profile of the Respondent}

The sample consists of a total of 94 respondents. Among the total sample size, $97.9 \%$ are male households and $2.1 \%$ are female. $72.3 \%$ of them are household heads and $67 \%$ of them have one or children to take care of. 31 one of them do not have any children. But, for the rest, the average number children per family are 5 of which $65 \%$ are below 18 years and $35 \%$ are above 18 years old. When we see the educational back ground, $61.7 \%$ of the population is either illiterate or under primary education level. $21.3 \%$ of them are at the level of secondary education (refer Table 1 and Table 2).

Moreover, $6.4 \%$ of them fall under TVET diploma and the rest $10.3 \%$ have degree and above. The data is collected based on the proportion of the concentration of farmers in the different market places.

Around $43 \%$ of the farmers have an experience of above fifteen years in selling agricultural products and in general, more than $80 \%$ of the farmers have more than five years of experience selling agricultural products (refer Figure 3).

Their production item consists of both cash crops and food crops. Out of the total population $69.1 \%$ produces cash crop as well as food crop. On the other hand, $11.7 \%$ produce only food crop and the remaining $19.2 \%$ produce solely a cash crop. The production of "Chat" takes the lion share their produce which is $82 \%$ followed by Enset $80 \%$, the main staple food in the area; Avocado 35\%, Cereal $33 \%$, Sugar cane $22.3 \%$, Vegetable $15 \%$ and Fruits $10.6 \%$ are the rest. This indicates that the majority of the farmers are engaged the production of more than one crop item.

Table 1. Descriptive statistics of Demographic and socio-economic profile of the respondent

\begin{tabular}{|c|c|c|c|c|}
\hline Items & Variable & Frequency & Percent & Cumulative $\%$ \\
\hline \multirow{3}{*}{ Sex } & Male & 92 & 97.9 & 97.9 \\
\hline & Female & 2 & 2.1 & 100 \\
\hline & Total & 94 & 100 & \\
\hline \multirow{4}{*}{ Age Distribution } & 18-29 years & 40 & 42.6 & 43 \\
\hline & $30-45$ years & 31 & 33 & 76.3 \\
\hline & Above 45 years & 22 & 23.4 & 100 \\
\hline & Total & 93 & 98.9 & \\
\hline \multirow{6}{*}{ Educational Status } & Illiterate & 22 & 23.4 & 23.4 \\
\hline & Primary level 1-8 & 36 & 38.3 & 61.7 \\
\hline & Secondary Level 9-12 & 20 & 21.3 & 83 \\
\hline & Degree and above & 10 & 10.6 & 93.6 \\
\hline & TVET Diploma & 6 & 6.4 & 100 \\
\hline & Total & 94 & 100 & \\
\hline
\end{tabular}


Table 2. Respondent's Number of Children

\begin{tabular}{l|ccccc}
\hline \multicolumn{1}{c|}{ Number of Children } & $\mathrm{N}$ & Minimum & Maximum & Mean & Std. Deviation \\
\hline Number of children below 18 years & 63 & 0.00 & 7.00 & 3.3016 & 1.44395 \\
Total number of children & 63 & 1.00 & 14.00 & 5.0159 & 2.62428 \\
Number of children above 18 years & 63 & 0.00 & 8.00 & 1.6984 & 1.87199 \\
\hline
\end{tabular}

Source: Own Survey and Computation, 2018

Table 3. Types of Production and selling distributions (N=94)

\begin{tabular}{l|cccc}
\hline Kind of Production & $\begin{array}{c}\text { Number of Producers of the item } \\
\text { from the total 94 farmers }\end{array}$ & $\begin{array}{c}\text { Percentage from the } \\
\text { total 94 farmers }\end{array}$ & $\begin{array}{c}\text { Sellers in the } \\
\text { market }\end{array}$ & $\begin{array}{c}\text { Percentage } \\
\text { of sellers }\end{array}$ \\
\hline Chat & 77 & $81.9 \%$ & 76 & $98.0 \%$ \\
Avocado & 33 & $35.1 \%$ & 26 & $78.8 \%$ \\
Sugar cane & 21 & $22.3 \%$ & 18 & $85.7 \%$ \\
Cereal & 31 & $33.0 \%$ & 16 & $51.6 \%$ \\
Fruits & 10 & $10.6 \%$ & 2 & $20 \%$ \\
Vegetable & 14 & $14.9 \%$ & 12 & $85.7 \%$ \\
Enset & 76 & $80.9 \%$ & 6 & $7.8 \%$ \\
\hline
\end{tabular}

Source: Own survey, 2018

Table 4. Market Delivery System-frequency

\begin{tabular}{l|ccc}
\hline Frequency of supplying to the market & Frequency & Percent & Cumulative Percent \\
\hline Quarterly & 41 & 44.1 & 44.1 \\
Semiannually & 42 & 45.2 & 89.2 \\
Annually & 9 & 9.7 & 98.9 \\
Total & 92 & 100 & \\
Missing System & 2 & & \\
\hline Total & 94 & & \\
\hline
\end{tabular}

Source: Own survey, 2018

Table 5. The Analysis of variance on the income of households: Farmers with and without access to market outlets and quality market information $(\mathrm{N}=94)$

\begin{tabular}{l|ccccc}
\hline Income of the Household & Sumof Squares & df & Mean Square & F & Sig. \\
Between Groups & 6682415761.5 & 3 & 2227471920.5 & 2.874 & .041 \\
Within Groups & 62013971262.2 & 80 & 775174640.77 & & \\
\hline Total & 68696387023.8 & 83 & & & \\
\hline
\end{tabular}

Source: Own survey, 2018

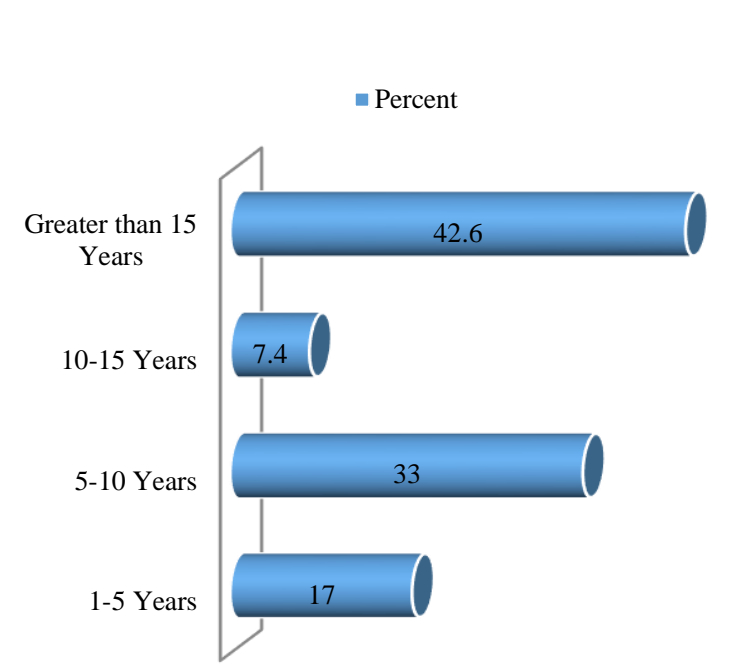

Figure 3. Years in selling Experience in selling agricultural produce

(Source: Own Survey, 2018)

Predicted by Observed

Target: Income of the Household

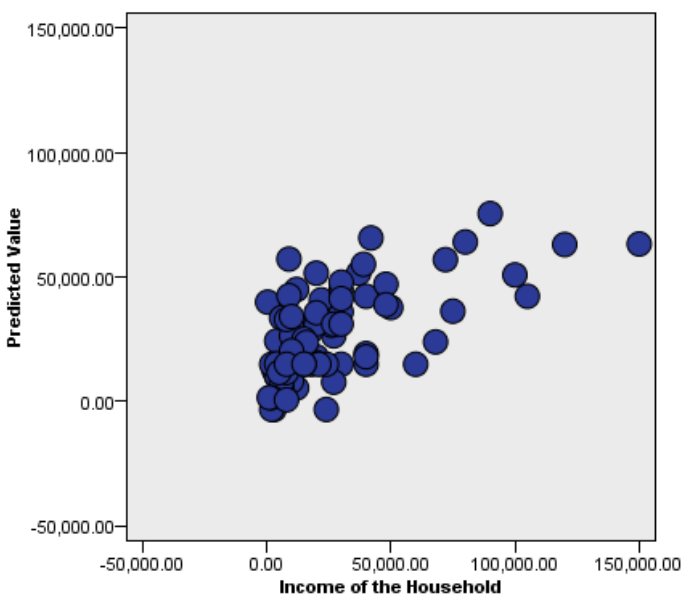

Figure 4. Econometric model of Income distribution of farmers

(Source: Own survey, 2018) 
Of the available cash crops, "Chat" is the most marketable product. 82 percent of the respondents produce "Chat" as their main production item, of which $98.7 \%$ of the producers or 76 of them bring their produce to the market. The second marketable product is vegetable in which out of the produce, $85.3 \%$ will be delivered to the market. The least marketed production is Enset. $82 \%$ of the producers produce Enset as one of their main production items. However, since it is mainly used for the consumption purpose, only $8 \%$ is traded in the market (refer Table 3).

When we see their sales destination, $99 \%$ of them sell their products to the nearby market and more than $88 \%$ of the farmers bring their production either quarterly or semiannually to the market and the rest being annual suppliers.

The income these smallholding farmers range from Birr 400 to 150,000 . The mean income is Birr 26,094 but there is high income disparity. This indicates that there is very big income inequality among the producers. The study categorized the farmers in to two groups (Those with market outlet and have access to timely information and others with little or no access) and compared the disparity in their income. As can be seen from the analysis of variance (ANOVA) test, there is a clear income disparity between the two groups. The highest return goes to those who have an outlet to their produce with access to relevant, timely, accessible information. The following table indicates this fact (Refer Table 4). $25 \%$ of the farmers get less than Birr 8000 annually and $50 \%$ of the sample get less than Birr 15,500 which is the median income of the farmers and still $75 \%$ of the farmers get less than Birr 30,000 per annum.

Basically, there are four market sites to sell their product. 70\% of them use "Chuko" as their market centre and around $22 \%$ use "Kella" as their common destination. The least used market centre is Beleche it is due to the distance from their residence. More than $70 \%$ of the farmers bring their produce to the market and the rest sell from their farm land. $87 \%$ of them do not have a constant customer to go and sell that puts them at the danger of selling their product below the mark-up price. In order to alleviate their problem, they were asked if they are willing to pay to get access to the relevant information to which all of them responded positively (Refer Table 6 and figure 4).

Concerning their financial status, only $31 \%$ of the respondents have any additional source of income other than their primary job. Despite the inaccessibility of banks, $80 \%$ of them aspire to save their money. Around $60 \%$ of them save at home; $34 \%$ at bank and the rest by lending to others (Refer Table 7).

Table 6. Income distribution of households $(\mathrm{N}=94)$

\begin{tabular}{l|l}
\hline Income of the Household \\
\hline Mean & 26094.0476 \\
Median & 15500 \\
Mode & 10000 \\
Std. Deviation & 28769.20773 \\
Variance & 827667313.5 \\
Range & 149600 \\
Minimum & 400 \\
Maximum & 150000 \\
Sum & 2191900 \\
\hline
\end{tabular}

Source: Own survey, 2018

Table 7. Preferred market places to sell produces $(\mathrm{N}=94)$

\begin{tabular}{l|ccc}
\hline \multicolumn{1}{c|}{ Market Places } & Responses & Percent & Percent of Cases \\
\hline Basha & 72 & 0.699 & 0.774 \\
Kella & 22 & 0.214 & 0.237 \\
Beleche & 2 & 0.019 & 0.022 \\
Aruma & 7 & 0.068 & 0.075 \\
\hline Total & 103 & 1 & 1.108 \\
\hline
\end{tabular}

Source: Own survey, 2018

Challenges of Small Holding Farmers to Access Quality Market Information

In order to facilitate the market exchange system and to assist unions, Wondogenet Wereda Exchange and Unions Bureau was established in 2010 with the aim of, connecting farmers to the market, promoting their products, certifying for the quality of their product, giving different trainings in order to upgrade their capacity, following the productionto-delivery processes of commercial products especially coffee and working in collaboration with Governmental and Non-Governmental Organizations like Ethiopian Commodity Exchange and Agricultural Groups Program (AGP).
However, there are various challenges that stayed long in the study area such as long prevailing illegal transactions, conflict and instability, absence of electronic price-display, challenges from rent seeking sellers (by tearing the price notice, threatening farmers to take price down, hindering them from being organized in unions, working through illegal ways etc.). There is also difficulty to work along with the farmers because of information and communication gap both on the very existence of the union its activities. Infrastructural problems, the spirit of monopoly by some cooperatives and the remoteness of some of the areas have made the outreach extremely difficult. Moreover, some of the officials since they 
themselves are in involved in the brokerage, they are reluctant in organizing the farmers.

The performance of the union is also far from success. For instance, in 2013/14, though it planned to collect 150 tons of coffee from the farmers, only 14.4 ton was collected. This was due to illegal merchants, lack of awareness by the farmers, lack coordination and the absence of controlling stations towards "Shashemene" and other outlets. On the other hand, the performance for food crops is very good and even some times the achievement is beyond the plan.

The market price is posted every week to update the market price to the farmers. The bureau has built one modern first instance market centre in "Kella" to facilitate its task. Despite these efforts, the market structure of "Wondogenet Wereda" is very traditional and backward. Products pass through many hands before they reach the final consumer. Using the following model, the researcher tried to show the traditional market system in the context of Wondogenet (refer Figure 5).
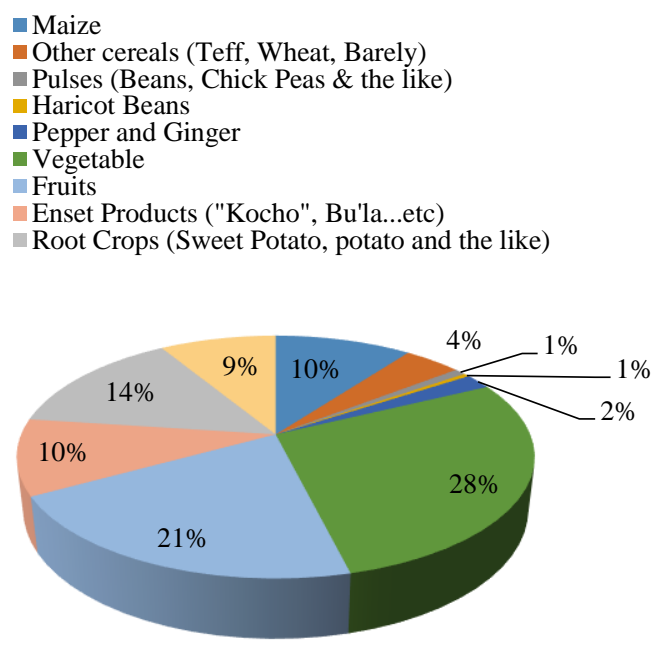

Figure 5. Share of products in Tons (Source: own survey, 2018)

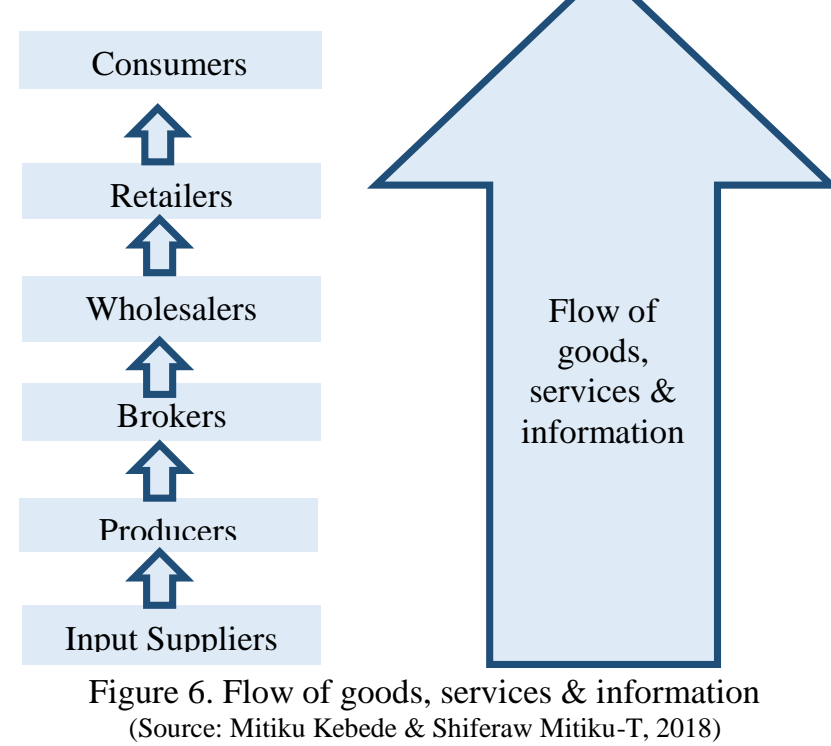

(Source: Mitiku Kebede \& Shiferaw Mitiku-T, 2018)
Even though farmers are the most important actors in the market, they were alienated from the major scene for long period of time. The following model is designed in order to bring the farmers to the arena once again to insure their benefit from the system. Farmers will deliver their produce not directly to the consumer rather to the exchange centre. The centre will deal on behalf of the farmers and they will get their fair market price. Since there is a back and forth information flow, the intermediary will be the union.

The Quality of Agricultural Market Information System for smallholding farmers in Ethiopia

In Wondogenet Wereda, $75 \%$ of the farmers get their information from rumours or friends which are, standing alone, very unreliable sources. $16 \%$ use brokers as their source of information which can be easily manipulative.

Only $5.3 \%$ of the respondents are able to use media as their source for information for decision-making. Regarding access to information media, other than the $6.5 \%$ respondents who did not own any medium of communication, more than $90 \%$ of them have at least have access to one communication medium. The most common one is mobile phone, which is owned by nearly $87 \%$ of the respondents. 37 percent of the respondents owned television or radio. More than $66 \%$ of the farmers have more than one media to access information (refer Table 8).

These farmers were asked to rate the information they get as very poor, poor, fair, good and excellent putting relevance, sufficiency, timeliness, and accuracy into consideration (refer Table 9).

When the overall response is rated, the majority of the respondents fall in the category of Fair (134.1\%), good $(101.1 \%)$ and poor $(77.5 \%)$ from quality of agricultural market information perspective in terms of Relevance, Timeliness, Accuracy and Sufficiency respectively. From the response, we can conclude that even if the information they get is relevant, there is big doubt on its timeliness, accuracy and sufficiency. The result also indicated that more than $75 \%$ of the respondents get information mainly from friends and rumours that are very unreliable. In addition, $91 \%$ of them either do not get information from the Exchange and Unions Bureau or do not know its existence at all. Around $25 \%$ respondents in one way or another experienced directly forwarded false information in their quest for market price. The outcome of this inconsistency is a very high disparity between selling and market price. More than $90 \%$ of the farmers claimed to have encountered a noticeable disparity between their selling price and final price in the market (refer Table 9).

Another aspect of this study is the need for the establishment of an information hub to provide timely, sufficient, relevant, and accurate information; $88 \%$ believe it will make a big difference in their life and are willing to pay to be a member.

The Effectiveness of Agricultural Market Information System for Small Holding Farmers in Ethiopia

According to Mesay (2007) and Agricultural Transformation Agency (2014), there are nine possible ways to share information to the small holding farmers in developing countries. These are: 
- Mass Media Based System-Information disseminated using Radio and Newspaper based Market Information System,

- Mobile Phone- Information disseminated using Short Messaging Service (SMS),

- $\quad$ Email Based System- users send and receive plain or formatted text messages via their email,

- Plasma Display Based System-is the display of daily prices on the plasma display screen,

- Market Information Points (MIPs) - Information displayed on the board of exchange bureaus,

- Telephone Based Query System-Calling relatives or someone close to market for information,

- Website Base Market Information system - Uses modern internet technologies to deliver

- Word of Mouth Based System-Getting information from neighbour or from people who recently visited market places and,

- Interactive Voice Response (IVR) Based SystemProvides interactive voice service using mobile phones

Based on result Table 10, these alternatives are measured using nine criteria which include, Accessibility, Availability (24/7), Ease of use, Implementation and operational cost, Information on demand, Localization for rural areas, Minimum technical skill required, and Realtime information delivery. The evaluation criteria developed took into consideration the educational situation of the country, technological trend, the existing infrastructure of the country, and the requirements of Ethiopian Commodity Exchange.
As can be seen from the table 10, after using the nine criteria, IVR based systems is selected to be very practical communication tool to deliver agricultural marketing information to rural areas (farmers). In the countryside where computer network infrastructure is not available, using the existing and fast expanding mobile/fixed telephone network for information services would be an ideal solution. Callers interface with the IVR based system through the telephone keypad. Very little technical knowledge is required to use IVR systems, in fact, no computer knowledge is needed. Given very little training, farmers who just know how to make a telephone call can use IVR based systems to get agricultural market information. Hence, in order to connect smallholding farmers with real time market information to help them take informed decision on their agricultural produce with minimum training and minimum infrastructure cost IVR based systems can be implemented in the rural Ethiopia to deliver valuable market information to farmers (refer Table 10).

\section{Alternative Value Chain Model to the Farmers}

In this model, the local unions' bureau: Wondogenet Unions Exchange Bureau (WEUB) is considered to be the hub of information and exchange. It will collect and gather the information from various stakeholders including the central government. Those small holding farmers and farmers in a cooperative could directly use the union as the main means to connect with exporters, agro-processors, local merchants or other cooperatives. Farmers with little production to take to the central market and those who did not get a chance to be in cooperatives also could get a good opportunity to directly meet their clients with the information they gathered from the centre.

Table 8. Sources of information for the farmers

\begin{tabular}{c|cccc}
\hline Sources & Media & Friends & Brokers & Rumor \\
\hline Percentage & $5.3 \%$ & $33 \%$ & $16 \%$ & $42.6 \%$ \\
\hline
\end{tabular}

Source: own survey, 2018

Table 9. Percentage of Respondents about the quality of agricultural market information

\begin{tabular}{l|ccccc}
\hline & Very Poor & Poor & Fair & Good & Excellent \\
\hline Relevance & $2.1 \%$ & $12.7 \%$ & $27.7 \%$ & $21.3 \%$ & $36.2 \%$ \\
Timeliness & $7.4 \%$ & $20.2 \%$ & $30.9 \%$ & $38.3 \%$ & $3.2 \%$ \\
Accuracy & $7.4 \%$ & $24.4 \%$ & $40.4 \%$ & $23.4 \%$ & $4.3 \%$ \\
Sufficiency & $10.6 \%$ & $20.2 \%$ & $35.1 \%$ & $18.1 \%$ & $16 \%$ \\
Overall quality & $22.2 \%$ & $77.5 \%$ & $134.1 \%$ & $101.1 \%$ & $59.7 \%$ \\
\hline
\end{tabular}

Source: own survey,2018

Table 10. The evaluation of the effectiveness of market Information Systems for small holding farmers in Ethiopia

\begin{tabular}{|c|c|c|c|c|c|c|c|c|c|}
\hline Effectiveness criteria & $\bar{A}$ & $\mathrm{~B}$ & $\mathrm{C}$ & $\mathrm{D}$ & $\mathrm{E}$ & $\mathrm{F}$ & $\mathrm{G}$ & $\mathrm{H}$ & $\mathrm{I}$ \\
\hline Mass Media Radio \& Newspaper) & Exc.* & Good & Good & Good & Exc. & $\mathrm{Bad}$ & V.G* & Good & Good \\
\hline Mobile Phone(SMS) & Exc. & Exc. & Exc. & $\mathrm{Bad}$ & V. G & V. G & Good. & Good & Exc. \\
\hline Interactive Voice Response (IVR) & Exc. & Exc. & Exc. & Exc. & V.G & Exc. & Exc. & V.G & Exc. \\
\hline Email Based System & Good & V.G & Good & V.G & Exc. & Good & V.G & Good & Bad \\
\hline Plasma Display Based System & V.G & Exc. & V.G & V.G & V.G & Good & V.G & V.G & V.G \\
\hline Market Information Points (MIPs) & V.G & V.G & V.G & V.G & V.G & Good & V.G & V.G & $\mathrm{Bad}$ \\
\hline Telephone Based Query System & Good & $\mathrm{Bad}$ & $\mathrm{Bad}$ & Good & Exc. & $\mathrm{Bad}$ & $\mathrm{Bad}$ & Exc. & $\mathrm{Bad}$ \\
\hline Website Base Market Information & V.G & Exc. & Exc. & Good & Good & Exc. & Exc. & Bad & Exc. \\
\hline Word of Mouth Based System & V.G & Bad & V.G & $\mathrm{Bad}$ & Exc. & Good & Exc. & Exc. & Bad \\
\hline
\end{tabular}

A: Accessibility, B: Accuracy, C: Availability, D: Ease of use, E: Operational cost, F: Info on demand, G: Localization, H: Low skill need, I: Real-time delivery, Source: Agricultural Transformation Agency and Own Survey, 2018 
The model shows both physical and financial flows of the items. The small holding farmers have two alternatives to sell their product. The first one is sending their produce directly to the agro processors (clock-wise) in the area and immediately cash out their produce. This line could basically be used for perishable fruits and vegetables. The second one is selling directly to the local merchants or connecting to international exporters using the information hub. In both cases, since the information asymmetry about existing market demand or prices could easily be accessed, these farmers will have increased understanding and bargaining power over the market. Therefore, instead of fragmented brokers at every stage, there will be one centralized and organized intermediary that could deliver the information and to deal the exchange. It also makes sure that the farmers are properly compensated and the payment reaches their hand in timely basis. The following diagram illustrates the proposed value chain model.

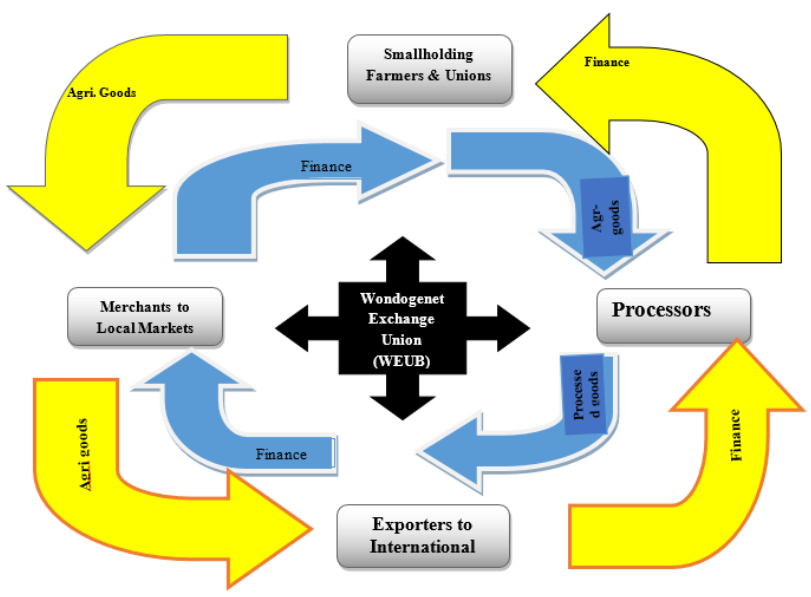

Figure 7. Alternative Value Chain Model for smallholding Farmers in Ethiopia

(Source: Mitiku Kebede \& Shifeaw Mitiku-T, 2018)

\section{Conclusions}

Market information service is a service that targets to increase the efficiency of farmers and to contribute towards overcoming basic issues of market failure based on asymmetrical access to information. It will increase their access to basic information that will enhance their bargaining power to negotiate for better prices from a position and assists the farmers to make informed decisions on how and where to sell their goods. Timely, speedy, relevant and accurate information packaged and delivered by low-cost technology-based systems can improve the competitiveness of smallholder farmers in the market place for better prices. Access to better markets and better prices mean better incomes for the farmer which is a way out from a vicious circle of poverty. Information is the foundation of the knowledge-based economy.

Farmers in Wondogenet Wereda are among the vulnerable groups due to deficient information access and delivery system. The study analysed the market linkage and information system gap in the study area. Though the system is very traditional and backward, there is a means to improve the situation and to bring them out of this dreadful condition eventually. One of the strategies to improve the market linkage is by using the value chain mechanism. Enhancing their back and forth communication system will assist these farmers to get out of the unidirectional, selectively beneficiary traditional system. This system guarantees their consistent and continuous attachment with the other supply chain actors in the market.

To facilitate the value chain mechanism, a complete market information access would be of no option. Even though there are plenty of options to deliver information to the farmers such as mass media (Radio and Newspaper) based system, mobile phone short messaging service (SMS), interactive voice response (IVR) based system, email based system, plasma display based system, market information points (MIPS), telephone based query system, website base market information system, and word of mouth based system, they are not equally important. The quality of Agricultural marketing information systems available for small holding farmers in Ethiopia were analysed using nine different criteria such as Accessibility, Availability (24/7), Ease of use, Implementation and operational cost, Information on demand, Localization for rural areas, Minimum technical skill required, and Realtime information delivery, these options were analysed.

The result indicated that interactive Voice Response (IVR) Based System, have a high return in satisfying the criteria. The fact is however, neither of these services is applied except the traditional Word of Mouth System and Market Information Point System. Due to lack of market information farmers sell their agricultural product to merchants at very low prices. They are easily manipulated by the asymmetric information they receive from various unauthenticated channels. Small holding farmers in Wondogenet Wereda are among the vulnerable groups due to deficient information access and delivery system.

In general, using Intermediary based value chain mechanism, making the Wondogenet Exchange and Unions Bureau as a centre of information and including agro-processors and exporters into the chain at large, it would be possible to guarantee the benefit of small-holding farmers. In addition, using IVR in local language to deliver farm related information would help to increase the production and productivity of farmers.

\section{Recommendation}

In order to create a well-functioning logistical (product and information) flow for perishable products in the agricultural product supply chain, the role of the government in establishing the platform is highly expected. This would lead to improvements in key metrics such as spoilage rates, lead times, and total logistics costs. Based on the findings the following action points are recommended.

- Restructuring the market information by bringing the most important wholesalers in to the system. This helps transaction data to be harmonized, summarized and disseminated directly to stakeholders.

- Enhancing the functionalities of the market information system by creating localized price data where the small holding farmers are more interested about and creating demand forecasting platform by 
distinguishing crops that continuously face marketing problems.

- Developing the information delivery system to farmers for easy access to not only price data but also information on new agricultural technologies, product information, and agriculture policies. In this case, as the study indicated earlier, Interactive Voice Response (IVR) is the most viable ways of communicating agricultural market information to small holding farmers.

In order to make these measures successful, incentivizing market actors to create a central, unified marketplace by joining Wondo Genet Union and Exchange and extending the connection to Ethiopian Commodity Exchange would not only consolidate their products and transport them in volumes by using the centralized union, but also reduces the total cost of delivery to end consumers. This will shorten lead times, keep products fresh longer, and reduce spoilage by bridging the multiple stages in fragmented markets.

In addition, trying to create uniform packaging standards and a harmonized product grading system would enhance vertical coordination throughout the agricultural logistics system and bring multiple benefits, including faster identification and processing of products and lower damage and loss rates.

On the other hand, enhancing the organization of stakeholders and logistics infrastructure through changing the way in which producers and distributors are organized and helping them develop their skills, though could take much longer time to implement successfully, it will have a long-term impact in increasing efficiency. Therefore, increasing economies of scale in production and distribution by consolidating farmers' cooperatives, encouraging the development of third-party logistics providers, that perform professional logistics services for farmers and the cooperatives, and nurturing further vertical coordination between production and retailing could transform the logistics system in a sustainable manner. Moreover, investing on the physical logistical infrastructure to support long-distance, high-volume agricultural product transportation modes and increasing the refrigerated storage capacity at wholesale markets to nurture Cold Chain Technologies is very crucial.

\section{Action Points for Unions Exchange Bureau}

- Most of the farmers are not aware of the existence of this institution. Even if its service is at grass root level, announcing its existence and functions properly is mandatory.

- $\quad$ Since the modern value chain system does not work by a single actor in its very nature, coordinated effort should be exerted to ensure the benefit at farmers, merchants and the union at each stage. Therefore, strengthening its interaction with the stakeholders by facilitating a back and forth information delivery mechanism is very important.

- The Unions Bureau should start to build the capacity of farmers by providing the trainings and awareness creations in continuously supplemented by a series follow ups
- In order to identify and control the illegal outlets through which various cash and food crops are moving out, more collaboration is required between the Union and government bodies in controlling the illegal transactions because not only the farmers are disadvantaged, the government is also losing its income in the process.

- Working in collaboration with governmental and nongovernmental organizations that provide related services such as Ethiopian Commodity Exchange is vital as the interaction has not passed from annual training services and meagre technical assistances.

\section{References}

Access Capital. 2012. Sector Review-Agriculture, Access Capital, Addis Ababa: Ethiopia

Agriculture Transform0ation Agency. 2014. How a new IVR/SMS service is revolutionizing the way Ethiopia's smallholder farmers access vital agricultural advice and information.http://www.ata.gov.et/programs/highlighteddeliverables/8028-farmer-hotline/ [accessed September 26, 2019].

Asian Development Bank. 2016. Asian Development Bank and the Development Research Center of the State Council, P. R. China. Improving logistics for perishable agricultural products in the People's Republic of China. Mandaluyong City, Philippines:

Cochran WG. 1977. Sampling Techniques. 3rd Edition, John Wiley \& Sons, New York.

Dralega CA. 2007. Rural women and ICT use in Uganda: Communities of practice and communication practices for development. In Proceedings of the 3rd Christina conference on women's studies and the 4th European gender and ICT symposium (pp. 8-10).

FAO. 2013. Analysis of incentives and disincentives for cocoa in Ghana. Rome. 4

FAO. 2015. The State of Food and Agriculture 2015- Meeting the 2015 International HungerTargets:Taking Stock of Uneven Progress. United Nations publication ISBN 978-925-107317-9, Rome.

FAO, ITU. 2016. E agriculture Strategy Guide, Piloted in AsiaPacific Countries. Bangkok, Thailand

FAO, ITU. 2017. E agriculture in Action, Bangkok, Thailand Ferris S., Robbins P., Best R.,

Ferris S, Peter R, Rupert B, Don S, Abbi B, Jefferson S, Emily W. 2014. Linking smallholder farmers to markets and the implications for extension and advisory services.MEAS Discussion Paper. [online] Available: https://www.researchgate.net/publication/285771192 Linking_smallholder_farmers_to_markets_and_the_implicat ions_for_extension_and_advisory_services/references [accessed December 23, 2019].

Grameen Foundation. 2014. Poor Users' Experience of Mobile Money in Nigeria. [online] Available: https://grameenfoundation.org/ documents/Nigeria-Landscape-resentation_Dec-2014.pdf[accessed December 20, 2019].

IFAD, UNEP. 2013. Smallholders, food security and the environment. Rome: International Fund for Agricultural Development

IMF World Outlook. 2017. Seeking Sustainable Growth. ShortTerm Recovery, Long-Term Challenges. [Online] Available: https://www.imf.org/en/PublicationsWEO/Issues/2017/ 09/19/ world-economic-outlook-october-2017 [accessed October 12, 2019].

Mesay Z. 2007. Market Information System and the Ethiopia Commodity Exchange,2007, AddisAbaba: Ethiopia.

Porter ME. 1985. Competitive advantage: Creating and sustaining superior performance. NY: Free Press 
Negassa GJ. 2015. Assessment of market linkages for smallholder farmers of coffee producers in Gihmbi Zone, Ethiopia. International Journal of Scientific and Research Publications.

Rao NH. 2007. A framework for implementing information and communication technologies in agricultural development in India. Technological Forecasting and Social Change, 74(4), 491-518.

Sen AK. 1962. An aspect of Indian agriculture. Economic Weekly, 14(4-6), 243-246.

Shepherd A. 2007. Approaches to linking producers to markets (Vol. 13). Food \& Agriculture Org.

Shepherd A. 2014. Contract farming: Partnerships for Growth"). FAO. Retrieved 25 February

SNNPR. 2017. Southern Nations, Nationalities and Peoples Region, Annual Livelihood Report

Tadele G, Gella AA. 2012. A last resort and often not an option at all: Farming and young people in Ethiopia. IDS Bulletin, 43(6): 33-43.

UNCTAD. 2015. Commodities and Development Report 2015 Smallholder Farmers and Sustainable Commodity Development United Nations Conference on Trade and Development. New York \& Geneva.
UNDP. 2012. Promoting ICT based agricultural knowledge management to increase production and productivity of smallholder farmers in Ethiopia

Von Braun J. 1995. Agricultural commercialization: Impacts on income and nutrition and implications for policy. Food Policy, 20(3): 187-202.

Vorley B, Lundy M, Macgregor J. 2008. Agro-Industries for Development: Business Models That Are Inclusive of Small Farmers. Edited by Carlos A. da Silva, Doyle Baker. Andrew W. Shepherd Chakib Jenane and Sergio Miranda-da-Cruz Published by The FAO and UNIDO [Online] Available: https://www.researchgate.net/publication/320558702 New_ business models_for_small_farmers_[accessed September 10, 2019].

World Bank. 2017. Economic Overview; Ethiopia at glance: Retrieved from: http://www.worldbank.org/en/ country/ ethiopia_[accessed September 15, 2019].

World Bank. 2008. World Development Report, Agriculture for Development. USA, Washington DC.

World Bank. 2012. World Bank, African Development Bank and African Development Fund (2012).ICTs for agriculture in Africa. [Online] Available: http://www.etransformafrica.org. [accessed December 23, 2019]. 